Article

\title{
Sustainable Public Procurement-External Forces and Accountability
}

\author{
Rob Vluggen *, Cees J. Gelderman, Janjaap Semeijn and Marc van Pelt
}

Department of Marketing \& Supply Management, Open University of the Netherlands, 6419AT Heerlen, The Netherlands; Kees.Gelderman@ou.nl (C.J.G.); Janjaap.Semeijn@ou.nl (J.S.); vanpelt15@hotmail.com (M.v.P.)

* Correspondence: robvluggen@gmail.com

Received: 8 September 2019; Accepted: 12 October 2019; Published: 15 October 2019

\begin{abstract}
Public agencies feel the need to advance sustainability and use procurement as an instrument to do so. Many studies focused on internal forces, explaining the limited success of sustainable public procurement. This study focused on how external forces are able to hold municipalities accountable for sustainable procurement. Three mid-sized Dutch municipalities were investigated through an extensive document study and $34 \mathrm{semi-structured}$ interviews. The results show minor legal pressure to enforce sustainable procurement. National legislation, guidelines and principles are considered non-binding, due to a lack of penalties in the case of non-compliance. Real pressure stems from lobbying by branch organizations and political pressure initiated by citizens. In contrast with the New Public Management principles, municipalities appear to place more emphasis on legal and financial accountability, in contrast to performance accountability. Accountants mainly focus on legitimacy and the finance department only monitors spending within budget. The hybrid organization of the procurement function seems to impede sustainability development. Only the larger projects are subject to sustainability requirements, set by centralized purchasing departments. Smaller projects, responsible for $2 / 3$ of the total spend are managed by decentralized groups, remaining under the radar of sustainability policies.
\end{abstract}

Keywords: public procurement; sustainability; external pressures; legal accountability; financial accountability; performance accountability

\section{Introduction}

Sustainable public procurement is gaining momentum throughout the European Union (EU) [1]. In the last decades, ever more governments have set legislation to encourage public agencies in developing sustainable public procurement. The general idea is that public authorities are more likely to embrace sustainability in a light-touch system than in an imposing, prescriptive system [2]. Sustainable public procurement is moving towards a more strategic role [3] as it has to achieve specific governmental objectives [4]. The procurement function has a crucial position in the development of sustainability by initiating and driving procurement projects [5].

In spite of reinforcement and support from national governments and procurement institutions, several studies indicate diverse success in the implementation of the roadmap towards a more sustainable attitude and compliant actions within governmental bodies, i.e., municipalities [6]. Some scholars show clear legislation is essential but missing $[7,8]$. The extent to which public procurement is moving towards sustainability and can be held accountable, depends on a great diversity of actors and factors. These actors and factors drive or hinder sustainability development and can be found in many studies on sustainable public procurement [5,9-17].

Some prominent factors include: institutional tardiness [5], resistance to change [18], omission of organizational targets, lack of procurement professionalism [10,12], knowledge and skills of 
sustainability [19], commitment by civil servants [18], and financial constraints [20]. As sustainable procurement procedures require adoption by purchasing employees and executive managers, support by the city council is needed [21]. Remarkably, only a few of these drivers and barriers relate to external actors and factors that influence sustainability development by public procurement. It appears that scholars tend to focus on internal organizational factors as drivers and barriers of sustainability.

The public sector represents substantial demand, which gives public procurement the potential to influence external actors. However, external actors are also able to influence public authorities and hold them accountable. Thai [22] presents a roughly defined public procurement model with four external pressures: legal, political, market and social-economic. Some authors have suggested that external forces could be more important to sustainable public procurement compared to internal forces $[17,23]$. However, a comprehensive investigation into the influence of external actors and factors on the development of sustainable public procurement remains relatively under-investigated. This is problematic, especially considering the growing influence of external actors [24]. This study addresses this gap, by focusing on external actors and factors and their influence on sustainable public procurement and to which extent local authorities are held accountable by these actors. The following research questions were formulated:

\section{Q1: What influence do external actors and factors have on sustainable procurement within municipalities?}

\section{Q2: How are municipalities held accountable for their sustainable procurement?}

To answer these questions, a multiple case study was carried out within three Dutch mid-sized municipalities, in order to explore external actors and factors, and their impact on sustainable public procurement. These municipalities were analyzed thorough document analysis and 34 in-depth interviews with internal as well as external actors.

In the next section, the theoretical framework on sustainable public procurement and accountability is discussed. Section 3, shows the methodology; in Section 4 the results are presented, Section 5 is the discussion and in Section 6 conclusions are presented, including the limitations and suggestions for future research.

\section{Literature Review}

This research uses the public procurement system [22] to understand the impact of external stakeholders on sustainable public procurement. The concepts of sustainable public procurement and accountability are presented, against which the role of external stakeholders is positioned, and to what extent they are able to hold public organizations accountable.

\subsection{Sustainable Public Procurement}

Public procurement represents a large portion of annual public spending and has been estimated to be around 20\% of the GDP across all EU member states [1]. Public procurement is the process by which central, regional, and local governments, governed by law and regulations, purchase goods and services [25]. The public procurement process has generally been intended as a rigid process narrowly aimed at the basic principles of European tendering policies [26]. However, given its economic significance, public procurement has the potential to influence markets in terms of sustainability development $[5,27]$. As a result, the public sector, through procurement, is able to contribute to sustainable objectives such as social equity, economic development, and ecological advantages [28].

Sustainable public procurement has been debated through theoretical and specific case study papers. According to Brammer and Walker [10], sustainable public procurement has been mainly considered by the public sector in order to stimulate the private market towards sustainability and creating awareness on the subject. In sustainable public procurement, the Triple Bottom Line is used to affect a balance in goal setting between economical, ecological, and social aspects of the goods and services procured $[10,14]$. Strategic sustainable goals in public procurement can be grouped into two categories, ecological and social [29], and according to Glas et al. [30] the integration of a broader 
concern for social and environmental issues is considered to be strategic within public organizations. In daily practice, achieving these more strategic goals seems to be quite difficult [14,21]. Glas et al. [30] show that the size of an organization has an influence on achieving goals. Large organizations are more capable of creating the right incentives for implementation of sustainable procurement [15]. While small organizations often struggle to facilitate the necessary incentives [21]. Furthermore, the internal discussion between purchasers, deputy managers, and the city council on the cost allocation of a more sustainable procurement policy is a major influencer [31]. This refers to the need for efficient spend of tax payer's money and accountability within municipalities [21].

Procurement departments need to extend traditional considerations to include the triple bottom line in organizational decision-making criteria and drive positive impacts in these areas through what they procure [32]. The ability for public procurement departments and private organizations to influence each other across a range of areas covering strategic and attitudinal issues [33], highlights the impact that parties can have on public and corporate sustainability [34].

Notwithstanding this reciprocal relationship, there remains a paucity of research on external actors participating and influencing public sector sustainability [12].

A study by Walker et al. [17] shows external drivers and barriers influencing environmental initiatives. Regulation has been found to be a major external driver of green procurement [35]. Environmental legislation is the backdrop for other drivers such as value champions' endeavors or risk minimization efforts [17]. Other external drivers are customer pressure, competitive advantage and pressure by NGO's. External barriers include regulation, as it also can inhibit sustainable practices, lack of supplier commitment, and industry specific barriers [17].

Despite many available tools and good initiatives, there is no consistent positive view on the results of sustainable public procurement [6]. Reasons could be the missing ambition [23], the limitation to minimum green requirements in tenders [36], the lack of maturity in strategy and execution [37,38] and/or the perceived additional costs of sustainability [20]. One way to promote sustainable procurement is by adopting more sustainable selection criteria in EU tenders [39]. Support comes from the EU Buying Green Handbook 2016, the 2012 Procurement Law in the Netherlands (effected in 2016), and sustainable guidelines from the government (PIANOo) for many product categories (www.pianoo.nl). However, these criteria lack legal status and as a result remain non-committal. Nevertheless, more and more municipalities use a strategic approach to make their procurement activities more sustainable [20,40], by preferably buying local and as sustainable as possible, despite all difficulties in legislation, government criteria, and complex stakeholder management [41].

\subsection{Public Procurement and Accountability}

In democracies citizens have delegated the provision of public services to public agencies which are controlled and governed by elected politicians. The interest of citizens is guarded and protected by a comprehensive system of accountabilities [2]. Accountability implies that an actor is held responsible for its actions and thus, is a process that involves an exchange of information between persons or organizations [42]. For this process to work, transparency is required [43], which can be achieved by sharing information about the performance of actors. The public sector accountability system includes different types of accountability: bureaucratic, legal, professional, and political [43,44]. Bureaucratic accountability refers to the relationship between employees and their superiors. Legal accountability contains the rules and regulations that public authorities are subjected to, while professional accountability is the control executed amongst peers. Political accountability refers to the relationship between elected politicians and citizens. According to Bovens [43], this categorization contains the essence of accountability in the public sector. Traditionally, public bodies emphasize procedural aspects ('how the government does what it does'), while as a consequence of New Public Management (NPM), public organizations are expected to focus on performance ('what government actually accomplishes') [45]. Within NPM, public organizations try to improve their efficiency by using private sector management ways of working [17]. As a result, national governments have given local 
public agencies more freedom as to how public services are delivered [46]. In this context, it is decisive for public organizations to be able to incorporate public values into directives and mission statements as well as politicians who are willing to endorse these public values [42].

In the last 20 years, procurement has made great progress in becoming a dynamic and strategic function within public organizations [14,22]. As procurement has matured, its influence on the sustainable approach of markets increases [5]. With respect to procurement in private organizations, public procurement is faced with specific additional requirements [22,31] as a result of a variety of stakeholders and their often conflicting and opposing interests [47,48]. Requirements such as accountability, responsiveness, and transparency, which refers to integrity and exemplary behavior [2]. These requirements influence internal procedures and processes, i.e., EU legislation, national governmental procurement laws, and governmental guidelines for sustainable procurement [36].

\subsection{Stakeholder Pressure}

The public sector in general and public procurement in particular, are held accountable for their actions, which implies interaction between persons or organizations [42]. Therefore, public organizations need to have a good understanding of salient stakeholders [19]. Stakeholder approach largely received attention after Freemans [49] published the book "Strategic Management, a stakeholder approach". Mitchell et al. [50] define three aspects to qualify the required attention (called 'salience') for any stakeholder: 'power', 'legitimacy', and 'urgency'. Identifying and classifying stakeholders based on these three aspects, results in a typology of stakeholders prioritizing the attention to be given to a specific stakeholder. Neville et al. [51] point at the 'continuum of these aspects', not by being present or absent or excluding each other but in relation and interaction of the aspects. In contrast to salience from the typology only, managers should pay attention to all stakeholders, regardless of the typology, which refers to the moral aspect of stakeholders' claims [51]. In particular, public organizations are externally oriented and confronted with diverse moral aspects fitting the interests of each group of stakeholders. In this perspective, stakeholders can be classified by 'extent of interest' and 'extent of power' [38,52].

Stakeholder pressure (customers, suppliers, interest groups, NGOs, and public authorities) on the private sector has increased [53]. This also applies to the public sector, were organizations are also faced with complex regulations and the risk of loss of reputation when non-complying [7]. Various studies conclude that stakeholders can be characterized as a driver as well as a barrier for an organization's sustainability $[7,17,19]$. A multiple stakeholder approach influences the reputation of public organizations [52] and contributes to a modern government [54]. A public organization must balance between a variety of interests which affects its policies, its sustainable objectives and, as a consequence, the procurement strategy [24,53]. As a result, stakeholder management is a must for public organizations [19].

\subsection{External Forces on Sustainable Public Procurement}

Several authors have stated that external forces, rather than internal forces, most prominently impact sustainable public procurement $[17,23]$. These studies stress the importance of cooperation within the supply chain and with non-business actors such as NGOs and labelling organizations. Continuous interaction between external and internal actors and factors also has an impact on developing sustainable public procurement [12]. Public organizations influence markets and are in their own way influenced by external actors, by generating pressure on policy development [23]. External actors all serve their own goals and these may be mutually conflicting $[28,48]$ as well as conflict with the public procurement system [22].

The system developed by Thai [22] is very useful when analyzing actors influencing public organizations. Besides internal forces influencing policy development, the system distinguishes four types of external forces; legal forces, political forces, market forces, and social and economic forces. However, focused on modern-day developments, the influence of individuals and groups is not easy to 
incorporate in the model. Walker et al. [17] focus on external drivers and mention society as a driver for sustainability development, albeit narrowed down to environmental pressure groups. To learn more about this growing external influencer, a fifth force was added to the Thai [22] system, societal forces. Table 1 shows the external forces influencing public procurement according to Thai [22], including the added societal forces.

Table 1. External forces influencing public procurement, based on Thai [22].

\begin{tabular}{|c|c|}
\hline External Forces & Main Themes \\
\hline Legal forces & $\begin{array}{ll}\text { - } & \text { Civil servants comply with rules and regulations [55]. } \\
\text { - } & \text { National procurement law (Aanbestedingswet 2012, AW2012). } \\
\text { - } & \text { Governmental sustainable guidelines (PIANOo) and individual } \\
\text { sustainable product categories. } \\
\text { - } \quad \text { Familiarity with legislation and supporting tools, encourages } \\
\text { compliance with sustainable standards [12]. }\end{array}$ \\
\hline Political forces & $\begin{array}{l}\text { Both internal and external with a relation to the principal-agent theory } \\
\text { [21]; political parties ('principal', external actor); majors and city } \\
\text { councils ('agent', internal actor). } \\
\text { - Four yearly installation of elected city council's election [56]. } \\
\text { - Probable conflicting interests between city council (politician, external) } \\
\text { and the civil servant (purchaser, internal) [21]. }\end{array}$ \\
\hline Market forces & $\begin{array}{l}\text { - 'Upstream' pressure from stakeholders within supply chains, such as } \\
\text { customers [11,57]. } \\
\text { - } \quad \text { 'Downstream' pressure from stakeholders in the trade-off between } \\
\text { sustainability and costs [57]. } \\
\text { - Public organizations support private sector organization sustainability } \\
\text { ambitions by initiating 'Green Deals' [36]. }\end{array}$ \\
\hline Social and Economic forces & 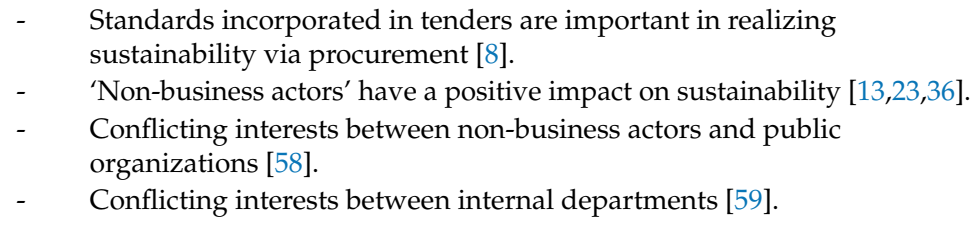 \\
\hline Societal forces & $\begin{array}{l}\text { - EU citizens expect public organizations to be transparent and hold them } \\
\text { accountable for including sustainability in tenders [60]. } \\
\text { - The private sector is forced to procure sustainable [54,61]. It remains } \\
\text { unclear if public procurement departments experience societal pressure } \\
\text { to procure sustainable. }\end{array}$ \\
\hline
\end{tabular}

By adding 'societal forces' to the Public Procurement System [22] (p. 33), this study tries to incorporate recent developments into the arena of influential stakeholders. In the last decade, markets and governments were forced into increasing transparency [2]. Due to technological developments, e.g., big data, internet, social media, transparency is forced upon organizations [31]. Also, external stakeholders are able to use modern technology to share information, cooperate in grass root initiatives and even enforce transparency by public organization. Recent research by Keulemans and Van der Walle [60] indicates that EU citizens expect their public authorities to evaluate other aspects besides costs such as quality and sustainability in public procurement.

The impact of societal forces on public organizations has not been investigated extensively. Obviously, municipalities have an external orientation on citizens and local society. According to Crespin-Mazet et al. [23], external stakeholders are involved in the creation of, as well as adjustments during, the process of developing sustainable procurement policies. 
This study investigates if society develops a force towards their public authorities, comparable with societal forces towards sustainable procurement in the private sector [54,61]. Specifically, it investigated communities, local media and media attention, public participation, civil protests, and disputes with public organizations. It is expected that municipalities do have a sustainable procurement policy but is unclear to which extent external stakeholders are able to influence the development of sustainable policies and projects. What are the dynamics of multiple stakeholders and external circumstances on public organizations? Are they in a position to enforce compliance and hold public organizations accountable?

\section{Research Method}

The empirical multiple case study focused on three midsized Dutch municipalities. The selection of these municipalities was based on location (spread over the country) and size (between 100,000 to 250,000 citizens). According to Zoeteman et al. [6], small municipalities ( $<100,000$ citizens) show little initiative in developing sustainability, and lack knowledge and professionalism, nor do they contribute to sustainability innovation. Their study also indicates large municipalities $(>250,000$ citizens) are very present in the field of sustainability development. Large municipalities have management control and are leading authorities on sustainability development [21]. Midsized municipalities on the other hand, are neither of both previous worlds and also have sustainability development. They have procurement professionals with the required knowledge and are also able to generate good incentives [6]. Also, midsized municipalities have not been specifically enclosed in academic research.

The design of this qualitative, exploratory study is aimed at investigating "a contemporary phenomenon in depth and within its real-life context" [62] (p. 4). The focus is on explanatory variables, external actors, and external factors, and their possible influence on sustainability development within public organizations. Policy adoption is characteristic for the dynamic environment within public organizations [30]. Within this dynamic environment, external actors and factors might influence each other, but also reinforce or attenuate policy development.

The research design has two parts; a case study and an analysis of policy documents on procurement and sustainability. The research provides methodological case variety and uses and expands the public procurement system [22] in exploring external stakeholders. This exploration gives new insights to what extent external stakeholders are able to hold public organizations accountable and have an influence on policy development [30]. Case study data were coded and analyzed thematically. An inductive approach was adopted with a focus on an inventory of external actors and factors in accordance with the four categories of the public procurement system [22] as well as to understand stakeholders' assumptions of accountability and sustainable procurement. The researchers took part in case study data collection activities, and each independently reviewed the data transcripts to identify emergent themes.

The empirical research started with studying internal documents from each municipality. The analysis of the policy documents was conducted in a structured process. First, initial reading of the provided documents. Second, individual scoring of the documents providing information on sustainable aspects and aspects of accountability. Information contained in documents can suggest questions that need to be asked and situations that need to be observed as part of the research. Third, analyzing the scorings matrixes and bridging to reveal connections between the documents and contexts [63]. The units of analysis for this study were three midsized municipalities in the Netherlands. The in-depth semi-structured interviews were held with respondents inside and outside these municipalities, adding up to a total number of 34 interviews. To promote openness in the interviews and prevent a possible defensive attitude among respondents, as many questions as possible were included related to (personal) experiences with and perceptions of sustainability development. The interviews were guided by a protocol which focused on questions regarding the process of developing the municipal sustainability policy, the sustainable procurement policy, how the policy was developed and which actors (both internal and explicitly also external) were involved. Also, 
respondents were asked if the policies' objectives were met and which actors are involved in the revising the policy. The respondents within the case organization were all key players in procurement processes and functionally involved. These respondents had the following functions: CEO, CFO, procurement manager, procurement advisor, facility manager, purchaser, and sustainability officer. Furthermore, the aldermen of each municipality as well as various members of each city council were interviewed. By conducting these interviews, we took notice of external actors to which respondents referred to as influencers. These actors were also invited for an interview, which gave the possibility to widen the context of the study. Key respondents on behalf of this group were employed by, or associated with the Ministry of Economic Affairs, NGOs, political parties, entrepreneur and trade associations, branch organizations, knowledge institutes, and citizen pressure groups.

\section{Results}

In this section the results are presented based on the comprehensive document analysis and interviews. In the first paragraph, the sustainability diffusion within the case organizations is presented. The second paragraph contains the role of external forces.

\subsection{Organization and Development of Sustainable Procurement}

Due to the economic recession between 2008 and 2014, municipalities suffered from cost savings and budget cuts. During this period, sustainability functions (officials) were minimized or even completely eliminated. The three case organizations are midsized municipalities and have a comparable organizational structure as well as employees (1200-1400). In all three case organizations, the need for a sustainable municipality was translated into the ambition of becoming climate neutral in the future. The pace at which each organization achieves its climate neutral ambitions varies from 2025 to 2050. Furthermore, each organization expects the procurement function to contribute to climate neutral objectives. The municipal organizations consist of expert groups such as an environmental office, engineering office, and healthcare offices, as well as functional departments such as finance and control and IT, and staff departments such as facilities, HR, legal affairs, and procurement. We found that accountants check for legitimacy of the process, and that the finance department monitors spending, while the effectiveness of sustainable procurement seems neglected. Apparently, with some exceptions, legal and financial accountability still prevail over performance accountability for achieving sustainability in municipalities.

Furthermore, our research results show that the chosen organizational structure has an impact on the development of sustainable procurement and the perception of pressure by external stakeholders. The cause of this deficiency appears related to the hybrid structure of the procurement function, were the procurement department supervises tenders above the threshold ( $1 / 3$ of the spend) and expert groups execute procurement activities under the threshold ( $2 / 3$ of the spend). The data shows that this division of tasks has an impact on the development of sustainability. The organizational position of the procurement function has a significant impact on the sustainable development of municipalities [21]. The organizational position of the purchasing function within all three municipalities is divided between expert groups for specific and specialized product categories and the staff function with internal consultants for the procurement strategy and advisory on large purchasing projects (European tenders). As a staff member stated: "We only consider the larger tender projects. There is not enough staff to supervise smaller projects." This lack of attention also refers to the accountants' control on purchasing projects: "We only assess financial issues in individual purchasing projects." Each organization strictly monitors tenders above the European threshold (1/3 of the spend) and these tenders are subject to sustainability requirements. However, the remaining $2 / 3$ of the spend comes from purchasing projects within decentralized expert groups, and therefore remains 'under the radar' with a lack incorporating and monitoring sustainable requirements. The data shows that the large tenders ( $1 / 3$ of the spend) are controlled by staff functions and, as a result, are more committed to sustainable procurement. It appears employees in staff functions are able to develop tenders with a 
broader approach and incorporate secondary elements in contracts, this is in contrast to specialists who apparently are more focused on primary technical specifications for their products and projects. Following these results, it can be assumed that municipalities achieve less sustainable results by limited tendering for their smaller purchases committed by expert groups (see Table 2). The data shows a solid embedding within organizations is crucial for a successful implementation of sustainable procurement. The municipalities have sustainable policies, incorporate these policies into their organization and report on the results, they struggle with the implementation within all section of the organization. Success depends on embracing the policy at all organizational levels, especially at the operational level. After all, a large part of the purchasing volume is plotted through low spend purchasing projects and therefore remains under the radar of the City Council and external stakeholders.

Table 2. Sustainable procurement in the investigated municipalities.

\begin{tabular}{|c|c|c|c|}
\hline Issue & Municipality 1 & Municipality 2 & Municipality 3 \\
\hline $\begin{array}{l}\text { Development of } \\
\text { sustainable } \\
\text { procurement }\end{array}$ & $\begin{array}{c}\text { Procurement strategy } \\
\text { contributes to a climate } \\
\text { neutral city. }\end{array}$ & $\begin{array}{l}\text { Sustainable procurement plays an } \\
\text { exemplary role. Goal is the } \\
\text { optimum in the triple bottom line. }\end{array}$ & $\begin{array}{l}\text { Sustainability is key. Goal of a } \\
\text { climate neutral city is } \\
\text { translated into sustainable } \\
\text { chain-oriented purchasing. }\end{array}$ \\
\hline $\begin{array}{l}\text { Tendering } \\
\text { procedures }\end{array}$ & $\begin{array}{l}\text { Sustainability criteria for large } \\
\text { public tenders ( } 1 / 3 \text { of the total } \\
\text { spend); less sustainability and } \\
\text { limited tendering for smaller } \\
\text { purchases (remaining } 2 / 3 \text { of } \\
\text { the spend). }\end{array}$ & $\begin{array}{l}\text { Limited tendering is used for a } \\
\text { large part of the total spend. } \\
\text { Inclusion of sustainability criteria } \\
\text { depends on decentralized } \\
\text { operational procurement. }\end{array}$ & $\begin{array}{l}\text { Sustainability criteria for large } \\
\text { public tenders ( } 1 / 3 \text { of the total } \\
\text { spend); less sustainability and } \\
\text { limited tendering for smaller } \\
\text { purchases (remaining } 2 / 3 \text { of } \\
\text { the spend). }\end{array}$ \\
\hline
\end{tabular}

Regarding the organizational position of procurement, external pressure on public procurement may thus enter at two functional levels within the organization: the purchaser in a decentralized expert group and/or the procurement consultant in the central staff. Procurement professional in the central staff are mainly focused on complying with legislation and regulations. They only push the boundaries of legislation if national guidelines and local policies force them to do so. This is narrowed down to the tenders above the threshold, which excludes all tenders beneath the threshold. Civil servants working in an expert group are mainly focused on substantive elements and lack the right knowledge to develop sustainability in tenders. The political function within the municipalities also operates at two levels: the alderman is part of the local government (internal actor) and at the same time is attached to his or her political party (external actor), who supervises the local government by the elected city councils. This group of respondents show that a factor of influence is the targeting of operational goals and activities of municipalities. The mayor and aldermen hold the governance functions and agree on ambitions and policies in a so called 'governance agreement' for a 4 year period. From these ambitions and policies, administrative top management defines the distracted goals into the operational functional areas. Top management reports on the progress of sustainability development to aldermen, the results are in accordance with the agreement. However, the aldermen indicate that it is very difficult to get a hold on the municipal organizations in the short time of their appointment. Clearly, there are tensions between party-political aldermen, procurement professionals, and department managers. In other words, the political ambitions of aldermen are curtailed by financial restrictions and limitations. Respondents working for the federal government state that their ambition is to develop legal means to exert pressure. They explicitly focus on the line between legitimacy and efficiency to facilitate procurement with stimulating legislation and the right resources. Respondents 
from branch organizations clearly focus on unambiguous procurement criteria, sustainable supply chains and certification. They are mainly focused on the efficiency aspect of sustainability. Regarding societal forces, all respondents do acknowledge societal forces as an important actor. Sustainable initiatives initiated by citizens are increasing in all cases and municipalities stimulate these initiatives. However, societal forces only seem to be concerned with sustainability development as a general concept and sustainable procurement policies in particular are neglected.

\subsection{External Pressures on Sustainable Procurement}

Interviews with key players and document analysis resulted in a cross-case analysis with insights into the influence of the five external factors [22] on the development of sustainable procurement, see Table 3.

Table 3. External forces on sustainable procurement.

\begin{tabular}{|c|c|c|c|}
\hline Issue & Municipality 1 & Municipality 2 & Municipality 3 \\
\hline Legal forces & $\begin{array}{l}\text { Use of sustainability guidelines } \\
\text { (PIANOo). However, no legal } \\
\text { enforcement due to a lack } \\
\text { of penalties. }\end{array}$ & $\begin{array}{l}\text { Compliance with laws and } \\
\text { regulations, adaptation of legal } \\
\text { sustainable requirements in } \\
\text { entire organization }\end{array}$ & $\begin{array}{l}\text { Handling legislation and } \\
\text { PIANOo guidelines; EMVI and } \\
\text { covenants are non-binding and } \\
\text { may restrict the desired } \\
\text { extra steps }\end{array}$ \\
\hline Political forces & $\begin{array}{l}\text { Aldermen define the reach of } \\
\text { city's ambition in the } \\
\text { governance agreement; city } \\
\text { council acts if there are } \\
\text { (negative) external signals. }\end{array}$ & $\begin{array}{l}\text { City council trusts aldermen to } \\
\text { execute procurement policies } \\
\text { according to the governance } \\
\text { agreement and reacts to } \\
\text { external signals. }\end{array}$ & $\begin{array}{l}\text { The political orientation of the } \\
\text { alderman and the city council } \\
\text { strongly impact sustainability } \\
\text { goals. Development and } \\
\text { execution of policies are } \\
\text { strictly separated. }\end{array}$ \\
\hline Market forces & $\begin{array}{l}\text { Branch organizations and } \\
\text { companies monitor tenders and } \\
\text { sometimes request other } \\
\text { specifications. No pressure is felt } \\
\text { if the legal obligations are met. }\end{array}$ & $\begin{array}{l}\text { A local business collective runs a } \\
\text { 'soft lobby' which results in more } \\
\text { attention for the local economy. }\end{array}$ & $\begin{array}{l}\text { Branch organization's lobbies } \\
\text { have influence; market } \\
\text { consulting enhances influence } \\
\text { but reduces the pressure on } \\
\text { sustainability. }\end{array}$ \\
\hline $\begin{array}{c}\text { Social and } \\
\text { economic forces }\end{array}$ & $\begin{array}{l}\text { The rankings published by } \\
\text { NGOs raise issues in local media } \\
\text { and meetings of the city council. }\end{array}$ & $\begin{array}{l}\text { NGO reports raise questions } \\
\text { that are discussed in meetings of } \\
\text { the city council. However, } \\
\text { policies are not adjusted as long } \\
\text { as legal obligations are met. }\end{array}$ & $\begin{array}{l}\text { Subject oriented NGOs are very } \\
\text { active, they are invited for } \\
\text { consultation by the local } \\
\text { government. Most commonly } \\
\text { consensus is achieved. }\end{array}$ \\
\hline Societal forces & $\begin{array}{l}\text { Citizens are being consulted on } \\
\text { sustainability issues. Local } \\
\text { initiatives are welcomed. No } \\
\text { attention for sustainable } \\
\text { procurement in particular. }\end{array}$ & $\begin{array}{l}\text { Local interest groups exert } \\
\text { pressure on sustainability. There } \\
\text { is pressure on sustainability in } \\
\text { general, not on sustainable } \\
\text { procurement in particular. }\end{array}$ & $\begin{array}{l}\text { Neighborhood councils are } \\
\text { actively involved in sustainable } \\
\text { initiatives. There is pressure on } \\
\text { sustainability in general, not on } \\
\text { sustainable procurement } \\
\text { in particular. }\end{array}$ \\
\hline $\begin{array}{l}\text { Most powerful } \\
\text { external force }\end{array}$ & $\begin{array}{l}\text { Most pressure from legislation } \\
\text { and PIANOo guidelines, as well } \\
\text { as the political orientation of the } \\
\text { aldermen and city council. }\end{array}$ & $\begin{array}{l}\text { Most pressure from legislation } \\
\text { and PIANOo guidelines. Focus } \\
\text { on local economy. Influence } \\
\text { from local interest groups. }\end{array}$ & $\begin{array}{l}\text { Most pressure from legislation } \\
\text { and PIANOo guidelines, as well } \\
\text { as the political orientation of the } \\
\text { aldermen and city council. }\end{array}$ \\
\hline
\end{tabular}

\subsubsection{Legal Forces}

National legislation and the PIANOo guidelines are at the base of (sustainable) procurement in all municipalities. However, these guidelines and principles are considered non-binding due to a lack of penalties in the case of non-compliance and an internal focus on legitimacy and financial aspects. According to an alderman: "The lack of monitoring and control is a barrier for the development of sustainable procurement." Apparently, legitimacy and legality prevail over appropriateness and efficiency in achieving sustainable procurement. However, external actors agree that local legal and political pressure, based on the ambitions of aldermen, are decisive for the development of sustainable procurement in municipalities. 


\subsubsection{Political Forces}

The generic sustainability policy is developed by the municipal council of (party-political) aldermen who have signed a management agreement for a period of 4 years. The members of the city council are not involved in defining the sustainable procurement strategy nor in the execution and implementation in separate procurement initiatives and projects. Members of the city council merely perform controlling tasks, feeling that they "assume that the 4 year management agreement is executed in a proper way". Political pressure arises when signals from society such as (local) businesses, (local) environmental groups, or NGOs lead to questions for the municipal council. It appears that councilors lack the knowledge and time to assess procurement dossiers on sustainability.

\subsubsection{Market Forces}

Municipalities only have to deal with market pressure if tenders are not executed according to legislation and accepted guidelines. Whenever called for, the legal affairs department will be involved in particular cases. Branch organizations, for instance for building construction and waterworks, monitor public tenders and incidentally request other specifications (municipality 1 and 3 ). In municipality 2 , a local business collective runs a rather soft but successful lobby for contracting local suppliers and stimulating the local economy. Actually, companies "have no means of pressure if municipalities can prove that they executed the purchasing process according to the Procurement Law 2012". This law does not enforce sustainable procurement; moreover, the PIANOo guidelines are non-committal. Possibly, market pressure is the strongest from social work companies, who are able to hold the municipality accountable for its legal obligations regarding social sustainability targets.

\subsubsection{Social and Economic Forces}

In all municipalities, NGO reports that include the ranking of municipalities on sustainability, raise questions and issues which are discussed in meetings with aldermen and the city council: "a bad position in rankings always leads to critical remarks and questions from city council members". One of the aldermen also pointed at the lack of pressure because: "Various researchers have different opinions on sustainable subjects". Such an observation offers a way out in delicate discussions. Again, aldermen experience no external pressure, if the legal obligations of a tender are met. The importance of certificates, hallmarks, and quality labels are recognized. Corresponding requirements are most commonly included in the list of requirements (municipality 1 and 2). Despite pressure from labor unions and local media, purchasing policies are never adjusted (municipality 2). Remarkably, trade unions only incidentally raise questions on the social part of the Triple Bottom Line approach and are, according to a city council member, "completely lacking in discussions on sustainable procurement".

\subsubsection{Societal Forces}

Generally, municipalities value open communication with their citizens. Local initiatives are welcomed and citizens are consulted about (local) sustainability issues (municipality 1 and 2). However, there is societal pressure on sustainability development in general, but there is no pressure on sustainable procurement in particular: "the procurement projects of the municipality as such are not a very sexy subject and do not interfere in any way with the regular interests from citizens". The most powerful external force in stimulating sustainable procurement within the three case organizations appears to be the Central Government with its 'Procurement Law' and PIANOo guidelines, even though these are quite ambiguous regarding sustainability issues. In fact, both national and local politics have the power to effectively realize a sustainable procurement strategy and implementation. 


\section{Discussion}

A major progress is undoubtedly that the procurement function is growing towards a more strategic position within public organizations which confirms earlier findings by [24,30]. Also, it is severely challenged by internal and external stakeholders which confirms the research by Gelderman et al. [12]. Attention and assurance for sustainability at a strategic organizational level is of great importance [14] and it appears municipalities have adopted this.

Besides all efforts in sustainability development, it appears that municipalities are mainly concerned with legal accountability within procurement projects. The extent to which legal pressure is exerted on municipalities to develop sustainable initiatives remains an important element [17]. We observed a lack of legal pressure to enforce sustainable buying, while legal enforcement is generally believed to have a significant impact [55]. In contrast with the principles of New Public Management [45], municipalities appear to put more emphasis on accountability for finances and process than on accountability for performance. All case-organizations have a good ranking in the sustainability index measured by the federal government. However, this index has a focus on sustainability development in general and integration of sustainable procurement within tenders above the threshold [36]. This reflects only $1 / 3$ of public procurement spending as $2 / 3$ of the spend is represented by projects beneath the threshold. Municipalities do develop sustainability initiatives, but still have a world to discover and improve their business operations. It can be concluded that sustainability development is gaining ever more attention by municipalities, but apparently, municipalities still have a long way to go in their pursuit of sustainable procurement.

Measuring the development of sustainable procurement is complex and this is why multiple studies report multiple interpretable positive trends towards sustainable procurement [6]. The results of this study reveal that the cause of these differences may be due to the lack of monitoring the smaller, non-European tenders. These tenders represent up to $2 / 3$ of the total purchase spend in Dutch municipalities, but are not monitored, and therefore, are not represented in data regarding sustainability development. The new national corporate social responsibility covenant on sustainable procurement intends to stimulate data collection and analysis, but is adopted by merely 50 (out of 380) municipalities in the Netherlands [64]. Because of this low amount of adoption, generating correct and valid data remains a point of concern for municipalities and scholars.

Both internal and external actors and factors influence sustainable procurement. Internally, the success of sustainable procurement depends on the relationship between three actors: alderman, purchaser, and budget owner. The relationship between these actors proves to be of crucial importance [21]. It is obvious that public organizations acknowledge their responsibilities and determine various sustainable policies, among them the procurement function with the incorporation of sustainable criteria [39]. The Triple Bottom Line approach [10,14] is well accepted as a starting point for sustainable procurement by the public sector, but the sector is also in need of up-to-date rules and regulations set by the federal government that does not just focus on regulations above the threshold, but also sets compelling guidelines for tenders beneath the threshold. Keulemans and Van der Walle [60] show that EU citizens do consider sustainable public procurement as very important. The three municipalities have developed sustainability cooperation with their inhabitants in order to accomplish regional and national sustainable objectives. However, within the case-organizations, the external pressure of citizens on sustainable procurement is not present. Nevertheless, there appears to be unanimous commitment to sustainability development and procurement should be added to the conversation between stakeholders. Sustainability development is on the radar, but there is still sufficient opportunity for improvement.

External stakeholders in the social field, such as local interest groups, closely follow sustainability development in the private sector [53]. Private organizations are forced to use ecologically responsible raw materials and sustainable production processes for their end product that are as green as possible $[9,11]$. The reviewing of external actors on the level of sustainable procurement suggests that the widely perceived societal pressure on private companies cf. [61] is non-existent in the public sector, 
due to a lack of interest for local administration and procurement. Sustainable criteria in public tenders do not encounter resistance from market parties, who in fact point out that public organizations do not fully benefit from all new (sustainable) technologies. From a legal point of view, innovation and co-creation may be difficult to develop in public-private partnerships, but there definitely is support for sustainable public procurement $[17,23]$. Furthermore, reports from NGOs exert pressure on the private sector and force markets and supply chains to reconsider their (production) strategies. In public organizations, the effect of these reports is delayed and has minimal impact. For municipalities, a poor sustainable ranking means extra attention from local politicians, which can lead to adding sustainable selection criteria in future tenders, but no more than that. There is an opportunity for public organizations to benefit more from external incentives from private organizations, especially because within their own organizations, purchasers lack time and money to fully focus on sustainability criteria. It would be beneficial for real pressure on sustainable procurement development to stem from lobbying by sector organizations, private organizations, and citizens.

Within the five external forces [22], most pressure stems from legal federal and local political forces. This observation refers more to the legality of the procurement process rather than the functionality of procured goods and services. The federal government sets standards (AW2012, Dutch Procurement Law), offers guidelines, and suggests a more sustainable way of procuring. However, despite good intentions, these initiatives are non-binding. The CEO of one of the case organizations stated: "our city reports sustainability results to the central government on a very regular basis, but we never receive any feedback". Politicians (aldermen, city council members, national political parties) can effectively stimulate and enforce new legislation and are able to make up-to-date sustainable guidelines applicable and binding. More compelling legislation and guidelines that do not only focus on tenders above the threshold, can also stimulate municipalities' administrative organizations in developing sustainable objectives and ensure pressure on changing default behavior within the internal organization $[17,18,41,55]$.

\section{Conclusions and Recommendations}

This multiple case study examined the influence of five external forces, i.e., 'legal forces', 'political forces', market forces', 'social and economic forces', and 'societal forces'. We observed a lack of legal pressure to enforce sustainable procuring. Real pressure appears to stem from lobbying by sector organizations, companies, and citizens. With some exceptions, we conclude that legal and financial accountability still prevails over performance accountability for achieving sustainable public procurement.

Sustainability receives attention, but the real effects are not easy to monitor. Decentralized purchasers lack time and money to fully focus on sustainability criteria. Therefore, a sound and reliable conclusion on the level of sustainable procurement within municipalities cannot be drawn. Moreover, sustainable execution of procured services by selected companies is not managed due to lack of time and money. Besides legality, procurement projects seem to have an increasing tendency towards functionality (alignment of purchasing with the city's ambition).

NGOs and labelling institutions are monitoring public procurement in order to accomplish their own objectives. They succeed in getting the attention from city council members and have their viewpoints and hallmarks taken seriously. It is definitely positive that they do not enforce new policies, but instead try to inspire politicians with new developments and ideas. Nowadays, city administrations acknowledge the role of citizens and let them participate in the development of a local strategy. Evermore, citizens are consulted for city planning programs as well as stimulated to participate in the pursuit of local goals such as the climate neutral city. Despite initially expected interaction between actors, they respect and sometimes consult each other, but never in a structural way.

Currently, public agencies have a delayed response to societal and political discussions and the, permanently applied, PIANOo guidelines are regarded as 'old fashioned'. Legislation should support the development from legality to functionality by taking an effort in making the overall 
procurement legislation more 'agile'. This can be achieved by focusing on best practices when developing legislation and also by generating a dynamic legislation. As a result, procurement officers will adopt functional sustainable criteria with more ease and confidence in their procurement projects. From this perspective, legislation will become 'evidence based' and will be able to impel procurement professionals. Unambiguous legislation could improve sustainable procurement, since municipalities show high levels of legal accountability and legal compliance. Still, critics could point out the benefits of administrative flexibility in combination with genuine enthusiasm for implementing sustainability [2]. Alternatively, municipalities could try to enhance and emphasize professional accountability, which refers to control executed amongst peers. Procurement professionals could be invited or urged to participate in regular peer review exercises [42]. These initiatives could stimulate the (non-legal) accountability for performance rather than accountability for processes or regulations.

The research has several limitations. The authors are aware that the case-organizations all have a good ranking on the sustainability index, which limited data collection. Also, it is inevitably very difficult to validate the honest reasons and dynamics within the projects and response by interviewees. Political and personal aspiration and actuality can get mixed-up. Further, the nature of public sector data provides information about only a small amount of sustainable practices in the selected municipalities. Also, this study is limited to Dutch municipalities because of their leading position in sustainable development. Future studies could address issues related to the effectiveness of legal pressure, for instance by investigating the gap between perceptions of legal pressure and the lack of enforcement. Major changes in sustainable public procurement take place within member states of the European Union. It is recommended to execute a 'pan-European study' into the external actors and factors and their impact on the development of sustainable procurement within Europe. Such research will make it possible to monitor the developments on a broader scale and will further add to the "EU Buying Green Handbook".

Author Contributions: Each author had significant contribution to this project and authorship is limited to the mentioned researchers. Each authors individual contribution: R.V. (analyses, data curation, formal analysis, writing, reviewing and editing, validation, visualization), C.J.G. (conceptualisation, formal analysis, methodology, project administration, supervision), J.S. (conceptualisation, formal analysis, methodology, project administration, supervision), M.v.P. (collecting data/investigation, formal analysis, resources, writing original draft preparation).

Funding: This research received no external funding.

Conflicts of Interest: The authors declare no conflict of interest.

\section{References}

1. EU Commission. Evaluation of Public Procurement Rules-Evaluation Report: Impact and Effectiveness of EU Public Procurement Legislation. 2017. Available online: http://ec.europa.eu/growth/single-market/ public-procurement/strategy_en (accessed on 25 May 2019).

2. Boeger, N. Reappraising the UK social value legislation. Public Money Manag. 2017, 37, 113-120. [CrossRef]

3. Patrucco, A.S.; Luzzini, D.; Ronchi, S.; Essig, M.; Amann, M.; Glas, A.H. Designing a public procurement strategy: Lessons from local governments. Public Money Manag. 2017, 37, 269-276. [CrossRef]

4. Walker, H. Public procurement research at IPSERA. Public Money Manag. 2015, 35, 141-144. [CrossRef]

5. Amann, M.; Roehrich, J.; Eßig, M.; Harland, C. Driving sustainable supply chain management in the public sector: The importance of public procurement in the European union. Supply Chain Manag. Int. J. 2014, 19, 351-366. [CrossRef]

6. Zoeteman, B.; Snoey, L.; Wentink, C.; Klein, M. How Ambitious do Municipalities Apply Sustainable Procurement? (In Dutch: Hoe Ambitieus Zetten Gemeenten Duurzaam Inkopen in?); Brabants Centre for Sustainable Development TELOS: Tilburg, The Netherlands, 2016.

7. Giunipero, L.C.; Hooker, R.E.; Denslow, D. Purchasing and supply management sustainability: Drivers and barriers. J. Purch. Supply Manag. 2012, 18, 258-269. [CrossRef]

8. Igarashi, M.; De Boer, L.; Michelsen, O. Investigating the anatomy of supplier selection in green public procurement. J. Clean. Prod. 2015, 108, 442-450. [CrossRef] 
9. Ageron, B.; Gunasekaran, A.; Spalanzani, A. Sustainable supply management: An empirical study. Int. J. Prod. Econ. 2011, 140, 168-182. [CrossRef]

10. Brammer, S.; Walker, H. Sustainable procurement in the public sector: An international comparative study. Int. J. Oper. Prod. Manag. 2011, 31, 452-476. [CrossRef]

11. Carter, C.R.; Rogers, D.S. A framework of sustainable supply chain management: Moving towards new theory. Int. J. Phys. Distrib. Logist. Manag. 2008, 38, 360-387. [CrossRef]

12. Gelderman, C.J.; Semeijn, J.; Vluggen, R. Development of sustainability in public sector procurement. Public Money Manag. 2017, 37, 435-442. [CrossRef]

13. Günther, E.; Scheibe, L. The Hurdle Analysis: A self-evaluation tool for municipalities to identify, analyse and overcome hurdles to green procurement. Corp. Soc. Responsib. Environ. Manag. 2006, 13, 61-77. [CrossRef]

14. Meehan, J.; Bryde, D. Sustainable procurement practice. Bus. Strategy Environ. 2011, 20, 94-106. [CrossRef]

15. Michelsen, O.; de Boer, L. Green procurement in Norway: A survey of practices at the municipal and country level. J. Environ. Manag. 2009, 91, 160-167. [CrossRef]

16. Preuss, L. Addressing sustainable development through public procurement: The case of local government. Supply Chain Manag. Int. J. 2009, 14, 213-223. [CrossRef]

17. Walker, H.; Di Sisto, L.; McBain, D. Drivers and barriers to environmental supply chain management: Lessons from the public and private sectors. J. Purch. Supply Manag. 2008, 14, 69-95. [CrossRef]

18. Grandia, J. Finding the missing link: Examining the mediating role of sustainable public procurement behavior. J. Clean. Prod. 2016, 124, 183-190. [CrossRef]

19. Schneider, L.; Wallenburg, C.M. Implementing sustainable sourcing-Does purchasing need to change? J. Purch. Supply Manag. 2012, 18, 243-257. [CrossRef]

20. Bratt, C.; Hallstedt, S.; Robèrt, K.-H.; Broman, G.; Oldmark, J. Assessment of criteria development for public procurement from a strategic sustainability perspective. J. Clean. Prod. 2013, 52, 309-316. [CrossRef]

21. Gelderman, C.J.; Semeijn, J.; Bouma, F. Implementing sustainability in public procurement: The limited role of procurement executives and party-political executives. J. Public Procure. 2015, 15, 66-92. [CrossRef]

22. Thai, K.V. Public procurement re-examined. J. Public Procure. 2001, 1, 9-50. [CrossRef]

23. Crespin-Mazet, F.; Dontenwill, E. Sustainable procurement: Building legitimacy in the supply network. J. Purch. Supply Manag. 2012, 18, 207-217. [CrossRef]

24. Oruezabala, G.; Rico, J.-C. The impact of sustainable public procurement on supplier management-The case of French public hospitals. Ind. Mark. Manag. 2012, 41, 573-580. [CrossRef]

25. Anschhoff, B.; Sofka, W. Innovation on demand-Can public procurement drive market success of innovations? Res. Policy 2009, 38, 1235-1247. [CrossRef]

26. EU. EU Tender Policy. 2012. Available online: https://europa.eu/youreurope/business/selling-in-eu/publiccontracts/public-tendering-rules/index.htm (accessed on 25 May 2019).

27. Yawar, S.A.; Seuring, S. Management of social issues in supply chains: A literature review exploring social issues, actions and performance outcomes. J. Bus. Ethics 2017, 141, 621-643. [CrossRef]

28. Nijaki, L.K.; Worrel, G. Procurement for sustainable local economic development. Int. J. Public Sect. Manag. 2012, 24, 133-153. [CrossRef]

29. McCrudden, C. Using Public Procurement to Achieve Social Outcomes. Nat. Resour. Forum 2004, 28, $257-267$. [CrossRef]

30. Glas, A.H.; Schaupp, M.; Essig, M. An organizational perspective on the implementation of strategic goals in public procurement. J. Public Procure. 2017, 17, 572-605. [CrossRef]

31. Telgen, J.; Harland, C.; Knight, L. Public procurement in perspective. In Public Procurement: International Cases and Commentary; Routledge: Oxford, UK, 2007; pp. 16-24.

32. Vachon, S.; Klassen, R. Extending green practices across the supply chain-The impact of upstream and downstream integration. Int. J. Oper. Prod. Manag. 2006, 26, 795-821. [CrossRef]

33. Meehan, J.; Wright, G.H. Power priorities: A buyer-seller comparison of areas of influence. J. Purch. Supply Manag. 2011, 20, 32-41. [CrossRef]

34. Meehan, J.; Bryde, D. A field-level examination of the adoption of sustainable procurement in the social housing sector. Int. J. Oper. Prod. Manag. 2015, 35, 982-1004. [CrossRef]

35. Zhu, Q.; Geng, Y.; Sarkis, J. Motivating green public procurement in China: An individual level perspective. J. Environ. Manag. 2013, 2013, 85-95. [CrossRef] [PubMed] 
36. Melissen, F.; Reinders, H. A reflection on the Dutch Sustainable Public Procurement Programme. J. Integr. Environ. Sci. 2012, 9, 27-36. [CrossRef]

37. Grandia, J.; Meehan, J. Public procurement as a policy tool: Using procurement to reach desired outcomes in society. Int. J. Public Sect. Manag. 2017, 30, 302-309. [CrossRef]

38. Johnson, G.; Scholes, K.; Whittington, R. Exploring Corporate Strategy; Prentice Hall: London, UK, 2005.

39. Testa, F.; Iraldo, F.; Frey, M.; Daddi, T. What factors influence the uptake of GPP (green public procurement) practices? New evidence from an Italian survey. Ecol. Econ. 2012, 82, 88-96. [CrossRef]

40. Adebayo, V.O. Exploring the impact of Procurement Policies, Lifecycle analyses and Supplier Relationships on the Integration of Sustainable Procurement in Public Sector Organisations: A Sub-Saharan African Country Context. Int. J. Sustain. Energy Dev. 2015, 4, 1. [CrossRef]

41. Thomson, J.; Jackson, T. Sustainable procurement in practice: Lessons from local government. J. Environ. Plan. Manag. 2007, 50, 421-444. [CrossRef]

42. Grossi, G.; Thomasson, A. Bridging the accountability gap in hybrid organizations: The case of Copenhagen Malmö Port. Int. Rev. Adm. Sci. 2015, 81, 604-620. [CrossRef]

43. Bovens, M. Public accountability. In The Oxford Handbook of Public Management; Ewan, F., Lynn, L.E., Jr., Pollitt, C., Eds.; Oxford Handbooks: Oxford, UK, 2005.

44. Greiling, D.; Spraul, K. Accountability and the challenges of information disclosure. Adm. Q. 2010, 34, 338-375.

45. Behn, R. Rethinking Democratic Accountability; Brookings Institution: Washington, DC, USA, 2001.

46. Deleon, L. Accountability in a 'reinvented' government. Public Adm. 1998, 76, 539-558. [CrossRef]

47. McCue, C.P.; Prier, E.; Swanson, D. Five dilemmas in public procurement. J. Public Procure. 2015, 15, $177-207$. [CrossRef]

48. Uyarra, E.; Flannagan, K. Understanding the innovation impacts of public procurement. Eur. Plan. Stud. 2010, 18, 123-143. [CrossRef]

49. Freeman, R.E. Strategic Management: A Stakeholder Approach; Pitman: Boston, MA, USA, 1984.

50. Mitchell, R.K.; Agle, B.R.; Wood, D.J. Towards a theory of stakeholder identification and salience: Defining the principle of who and what really counts. Acad. Manag. Rev. 1997, 22, 853-886. [CrossRef]

51. Neville, B.A.; Bell, S.J.; Whitwell, G. Stakeholder salience revisited: Refining, redefining, and refueling an underdeveloped conceptual tool. J. Bus. Ethics 2011, 66, 377-391. [CrossRef]

52. Williams, W.; Lewis, D. Strategic management tools and public sector management. Public Manag. Rev. 2008, 10, 653-671. [CrossRef]

53. Engert, S.; Baumgartner, R.J. Corporate sustainability strategy-Bridging the gap between formulation and implementation. J. Clean. Prod. 2016, 113, 822-834. [CrossRef]

54. Foo, L.; Asenova, D.; Bailey, S.; Hood, J. Stakeholder engagement and compliance culture. Public Manag. Rev. 2011, 13, 707-729. [CrossRef]

55. Grandia, J.; Steijn, B.; Kuipers, B. It is not easy being green: Increasing sustainable public procurement behavior. Innov. Eur. J. Soc. Sci. 2015, 28, 243-260. [CrossRef]

56. Walker, H.; Brammer, S. Sustainable procurement in the United Kingdom Public Sector. Supply Chain Manag. Int. J. 2009, 14, 128-137. [CrossRef]

57. Reuter, C.; Goebel, P.; Foerstl, K. The impact of stakeholder orientation on sustainability and cost prevalence in supplier selection decisions. J. Purch. Supply Manag. 2012, 18, 270-281. [CrossRef]

58. Bügl, R.; Stauffacher, M.; Kriese, U.; Lehmann Pollheimer, D.; Scholz, R. Identifying stakeholders' views on sustainable urban transition: Desirability, utility and probability assessments of scenarios. Eur. Plan. Stud. 2011, 20, 1667-1687. [CrossRef]

59. Hoejmose, S.U.; Adrien-Kirby, A.J. Socially and environmentally responsible procurement: A literature review and future research agenda of managerial issues in the 21st Century. J. Purch. Supply Manag. 2012, 18, 232-242. [CrossRef]

60. Keulemans, S.; Van de Walle, S. Cost-effectiveness, domestic favouritism and sustainability in public procurement: A comparative study of public preferences. Int. J. Public Sect. Manag. 2017, 30, 328-341. [CrossRef]

61. Wolf, J. The Relationship between sustainable supply chain management, stakeholder pressure and corporate sustainability performance. J. Bus. Ethics 2014, 119, 317-328. [CrossRef] 
62. Yin, R.K. Case Study Research: Design and Methods, 5th ed.; Sage Publications: Thousand Oaks, CA, USA, 2014.

63. Prasad, A. The contest over meaning: Hermeneutics as an interpretive methodology for understanding texts. Organ. Res. Methods 2002, 5, 12-33. [CrossRef]

64. Pianoo. Manifest Maatschappelijk Verantwoord Inkopen 2016-2020 (Manifest MVI). 2016. Available online: https://www.pianoo.nl/sites/default/files/documents/documents/manifest-maatschappelijkverantwoord-inkopen-2016-2020.pdf (accessed on 15 May 2019).

(c)

(C) 2019 by the authors. Licensee MDPI, Basel, Switzerland. This article is an open access article distributed under the terms and conditions of the Creative Commons Attribution (CC BY) license (http://creativecommons.org/licenses/by/4.0/). 